http://www.atbp.onaft.edu.ua/

[15] Kafarov, V.V. Osnovy massoperedachi. Moskva, Vysshaja shkola, 439 s., 1979.

[16] Demidenko, N.D., Kulagina, L.V. Distributed control for systems with distributed parametres. J. Sib. Fed. Univ. Eng. technol, 11 (2), P. 221-228, 2018. https://doi.org/10.17516/1999-494X-0025

[17] Sheikus, A.R., Tryshkin, V.Ja., Levchuk, I.L. Modeljuvannja procesu bagatokomponentnoi' rektyfikacii' $z$ vrahuvannjam ruhlyvyh kerujuchyh vplyviv. Komp'juterne modeljuvannja: analiz, upravlinnja, optymizacija, 1(3), S. 82-91, 2018.

[18] Sheikus, A., Belobrova, E., Dovgopoliy, Ya., Levchuk, I., Korsun, V. Developing a technique for improving the efficiency of iterative methods for the calculation of the multicomponent rectification process. Eastern-European Journal of Enterprise Technologies, Vol. 6, N 2 (84), P. 38-44, 2016. https://doi.org/10.15587/1729-4061.2016.85372

[19] Sheikus, A.R., Trishkin, V.Ya. Static optimization of rectification processes using mobile control actions. Radio Electronics, Computer Science, Control, 1, P. 192-201, 2018. https://doi.org/10.15588/1607-3274-2018-1-22

[20] Sheikus, A.R., Levchuk, I.L., Trishkin, V.Ja., Korsun, V.I. Modelirovanie parozhidkostnogo ravnovesija pri podvizhnom upravlenii processami rektifikacii. Vestnik NTU "HPI". Serija: Informatika i modelirovanie, 44 (1216), S. 87-100, 2016. https://doi.org/10.20998/2411-0558.2016.44.08

[21] Sheikus, A.R., Levchuk, I.L., Trishkin, V.Ja. Upravlenie processom rektifikacii s ispol'zovaniem podvizhnyh upravljajushhih vozdejstvij s dvumja stepenjami svobody. Integrirovannye tehnologii i jenergosberezhenie, 1, S. 60-72, 2017.

УДК 697

\title{
ДОСЛІДЖЕННЯ ПРОЦЕСІВ УТИЛІЗАЦІЇ ТЕПЛА ПАРОПОВІТРЯНИХ СУМІШЕЙ: ІМІТАЦЙНЕ МОДЕЛЮВАННЯ
}

Ковальчук Д. А. ${ }^{1}$, Мазур О. В. ${ }^{2}$

Одеська національна академія харчових технологій, вул. Канатна, 112, Одеса, 65039, Україна

${ }^{1}$ асистент, ${ }^{2}$ доцент, к.т.н.

ORCID: ${ }^{1}$ 0000-0003-0549-5244, ${ }^{2}$ 0000-0001-7104-9010

E-mail: ${ }^{1}$ radiolomaster@gmail.com, ${ }^{2}$ mazur.av.ua@gmail.com

Copyright (C) 2018 by author and the journal "Automation of technological and business - processes. This work is licensed under the Creative Commons Attribution International License (CC BY). http://creativecommons.org/licanses/by/4.0

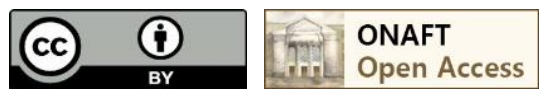

DOI:

\section{Анотація.}

Розглянуті основні підходи до розробки імітаційних моделей, освітлені їх недоліки та переваги. Розглянута імітаційна модель процесу глибокої утилізацї тепла пароповітряних сумішей з використанням парокомпресійного теплового насосу, до складу якої входять імітаційні моделі компресора, конденсатора, електронного розширювального вентиля, випарника, переохолоджувача та контактного теплообмінника - утилізатора тепла пароповітряних сумішей. Імітаиійні моделі ичих складових побудовані з використанням експериментальних даних, отриманих авторами в результаті виконання фізичних натурних експериментів на лабораторній дослідній установці. В імітаційній моделі випарника теплового насосу реалізовано функцію розрахунку «баластної» та «ефективної》 витрати холодоагенту. «Баластна» витрата виникає за рахунок переохолодження холодоагенту до температури кипіння $і$ супроводжується випаровуванням його частки, яка не приймає участі у відборі тепла випарником. Для ичього до імітаційної моделі випарника була додана підсистема розрахунку перепаду температур кипіння (тиску) по довжині випарника в залежності від витрати холодоагенту та температурного напору у випарнику, що враховує довжину ділянки випарника на якій відбувається кипіння рідкої фази. Залежність перепаду тиску по довжині випарника від витрат холодоагенту через нього є не монотонно зростаючою функцією а має екстремум і спадає при рівнях перегріва холодоагенту від 15 до $0{ }^{\circ} \mathrm{C}$. Тиск на виході випарника розраховується в 
http://www.atbp.onaft.edu.ua/

моделі з використанням нелінійної функиї двох змінних - положення електронного розширювального вентиля та частоти обертання компресора. Динамічні властивості каналів моделюються ланками, передатні функиії яких були отримані в результаті фізичних експериментів. Проведена перевірка розробленої імітаційної моделі на адекватність, для чого було організовано ряд комп'ютерних експериментів з умовами, аналогічними умовам проведення натурних фізичних експериментів. Порівняння результатів моделювання та фізичного експерименту показало високу ступінь їх схожості.

\section{Annotation.}

The article considers basic approaches to the development of simulation models, their advantages and disadvantages. The article outlines the simulation model for deep heat recovery process of steam-air mixtures with steam-compressor heat pump, including simulation models of the compressor, condenser, electronic expansion valve, evaporator, supercooler and contact heat exchanger recovering heat from steam-air mixtures. The simulation models of these components wereprepared using experimental data obtained by the authors as a result of performing physical field experiments at a laboratory test facility. The function of calculating the "ballast" and "effective" refrigerant flow is implemented in the simulation model of the heat pump evaporator. "Ballast" flow occurs due to the refrigerant supercooling to boiling point and is accompanied by partial evaporation of its share, which does not take part in the heat extraction by the evaporator. To do this, the evaporator simulation model was supplemented with a subsystem calculating the difference in boiling points (pressure) along the length of the evaporator based on the refrigerant flow rate and the evaporator temperature and taking into account the length of the evaporator segment where the liquid phase boils. Dependence of the pressure drop along the length of the evaporator on the refrigerant flow passing through it, is not a monotonically increasing function but is that having an extremum and decreasing at the refrigerant overheating levels ranging from 15 to $0{ }^{\circ} \mathrm{C}$. Evaporator outlet pressure is calculated in the model using a nonlinear function of two variables - the position of EEV and the compressor's rotational speed. The dynamic properties of the channels are modelledbased the links which transfer functions were obtained as a result of physical experiments. The adequacy of the simulation model was tested and a series of computer experiments were performed under conditions similar to those of the full-scale physical experiments at the laboratory facility. Comparison of simulation results and physical experiment showed a high degree of similarity.

Ключові слова: дослідження, імітаційна модель, моделювання, тепловий насос, утилізація тепла, пароповітряна суміш, статичні характеристики, динамічні характеристики, компресор, випарник, конденсатор, переохолоджувач, електронний розширювальний вентиль.

Keywords: research, simulation model, simulation, heat pump, heat recovery, steam-air mixture, static characteristics, dynamic characteristics, compressor, evaporator, condenser, supercooler, electronic expansion valve

\section{1. Вступ}

Сучасні підходи до розробки та дослідження систем управління передбачають застосування імітаційних моделей об'єктів управління. () Для розробки енергоефективних алгоритмів управління процесом глибокої утилізації ППС необхідно створити його імітаційну модель, що більш-менш адекватно відображає властивості реальної фізичної системи утилізації.

Існують різні підходи до побудови таких моделей. Деякі з них орієнтовані на розрахунок конструктивних особливостей елементів системи $[11,16,17,18]$. Однак такий підхід призводить до того, що моделі містять велику кількість емпіричних коефіцієнтів, необхідних для розрахунку конструкції даних агрегатів. Ці моделі відрізняються достатньою громіздкістю, включають велику кількість емпіричних коефіцієнтів та в решті решт дають досить великий розкид значень розрахункових параметрів і зазвичай слабо відображають динамічні властивості модельованих елементів системи, які дуже важливі при побудові систем управління.

Інший, спрощений підхід до розрахунку таких систем $[3,9,13,14]$ зазвичай полягає в застосуванні моделей елементів системи з зосередженими параметрами, без урахування їх конструктивних особливостей. Він зазвичай зводиться до розрахунку основних параметрів процесів на підставі термодинамічних властивостей теплоносіїв, а також теплових і матеріальних балансів системи. При цьому матеріальний баланс описується умовою нерозривності, тобто рівністю масової витрати теплоносія через послідовно включені елементи системи, а тепловий - визначається законом збереження енергії і описується рівняннями теплового балансу.

Застосована при розробці та дослідженні алгоритмів керування імітаційна модель процесу УТППС може бути побудована на основі моделей елементів із зосередженими параметрами, однак вона повинна адекватно відображати фізичні, статичні і динамічні властивості елементів системи. Дослідженню динамічних і статичних властивостей процесів глибокої утилізації тепла пароповітрянихсумішей (УТПВС) з використанням парокомпресійного теплового насоса були присвячені роботи $[1,2]$.

Ця стаття стосується розробки імітаційної моделі процесу УТПВС, реалізації іï в середовищі Simulink і перевірки на адекватність

\section{2. Розробка імітаційної моделі}

\section{1. Загальна структура імітаційної моделі}

У статтях $[1,2]$ була описана і досліджена фізична модель системи глибокої утилізації тепла ППС, яка складається 3 парокомпресійного теплового насоса типу "вода-вода" i контактного теплообмінника-утилізатора. Структура 
імітаційної моделі була обрана відповідно до структури описаної в [2] фізичної моделі. Взаємозв'язки між елементами моделі також відповідають фізичним параметрам.

Структурна схема імітаційної моделі представлена на рисунку 1.

До її складу входять моделі: ЕРВ (1), випарника (2), компресора (3), конденсатора (4), переохолоджувача (5) i контактного теплообмінника-утилізатора (6). Взаємозв'язки між ними відображають основні матеріальні та енергетичні потоки процесу. В системі присутні 2 основних контури в яких зберігається матеріальний і енергетичний баланси [7, 10]. Контур холодоагенту парокомпресійного теплового насоса "Вода - вода" і водяний контур теплоутілізатора. Контур холодоагенту включає в себе компресор, конденсатор, ЕРВ, переохолоджувач і випарник. Умова матеріального балансу (нерозривності) визначає те, що масова витрата холодоагенту $G_{M}$ через всі елементи цього контуру однакова.

$$
G_{M}=G_{M n n}=G_{M x d}=G_{M n}=G_{M e q e}=G_{M e}
$$

де $G_{M x n}-$ масова витрата холодоагенту через компресор;

$G_{\text {Mхð }}$ - масова витрата холодоагенту через конденсатор;

$G_{M n}$ - масова витрата холодоагенту через переохолоджувач;

$G_{\text {Mepe }}$ - масова витрата холодоагенту через ЕРВ;

$G_{M ब}-$ масова витрата холодоагенту через випарник.

Умовою безаварійного ведення технологічного процесу УТПВС є газоподібний стан холодоагенту на вході компресора. Рушійною силою, що забезпечує циркуляцію холодоагенту, є перепад тисків, який створюється компресором. Рівень тиску парів холодоагенту на вході компресора забезпечує виконання умови матеріального балансу - рівності масової витрати холодоагенту через ЕРВ і компресор. Рівень тиску парів холодоагенту на виході компресора визначається режимом роботи конденсатора.

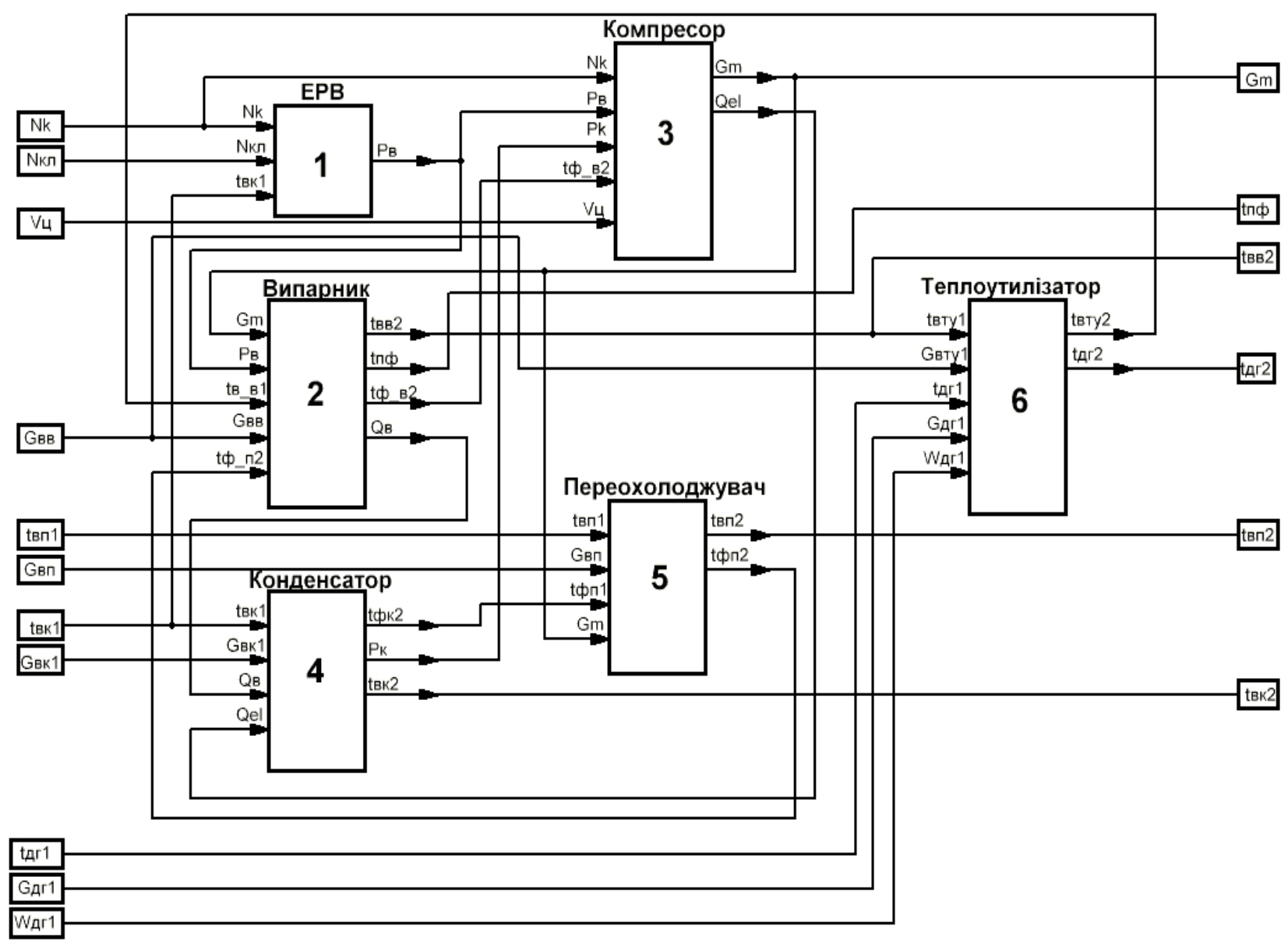

Рис. 1 - структурна схема моделі теплонасосного утилізатора тепла ППС

Водяний контур включає в себе контактний теплообмінник повітря-вода і випарник. В ньому відбувається конденсація частини вологи з ППС і за рахунок цього збільшення маси води в контурі. Однак в системі присутній пристрій для відводу зайвої води що підтримує постійну масу охолоджуючої води в контурі. 
Енергетичний (тепловий) баланс процесу УТПВС без урахування втрат в навколишнє середовище описується рівністю теплових потужностей:

$$
P_{T Y}=P_{B}=\left(P_{K D}+P_{I I}-P_{K \Pi}\right)
$$

де $P_{T y}$ - потужність контактного теплообмінника;

$P_{B}$ - потужність випарника;

$P_{K \not}$ - потужність конденсатора;

$P_{I I}$ - потужність переохолоджувача;

$P_{K I I}$ - потужність компресора.

\section{2. Імітаційна модель ЕРВ}

Імітаційна модель ЕРВ (1) побудована на основі експериментальних досліджень статичних та динамічних властивостей процесу УТППС, викладених у $[1,2]$. Вхідними параметрами для моделі ЕРВ $є$ положення ЕРВ, частота обертання компресора та температура води на вході в конденсатор. Вихідний параметр моделі - тиск на виході випарника, який є функцією трьох змінних. Дві 3 них - положення клапану ЕРВ (N $\left.{ }_{\mathrm{kn}}\right)$ та частота обертання компресора $\left(\mathrm{N}_{\mathrm{K}}\right)$ - зазвичай виконують функції керуючих впливів в системі керування. Статичні властивості цієї залежності описуються функцією двох змінних.

$$
\mathrm{P}_{\phi \mathrm{QB} 2}\left(\mathrm{~N}_{\mathrm{KH}} \mathrm{N}_{\mathrm{K}}\right)=\left(\frac{1500}{88+\mathrm{N}_{\mathrm{K}}}\right)-0.03 \cdot \mathrm{N}_{\mathrm{Kn}} \cdot \mathrm{N}_{\mathrm{K}} \cdot\left(1-e^{\frac{\mathrm{NkN}}{50}}\right)
$$

де $\mathrm{P}_{\phi в 2}$ - тиск холодоагенту на виході випарника

$\mathrm{N}_{\mathrm{K} \pi}$ - положення клапана ЕРВ;

$\mathrm{N}_{\mathrm{K}}$ - частота обертання компресора

На рисунку 2 представлена реалізація цієї залежності у середовищі Simulink:

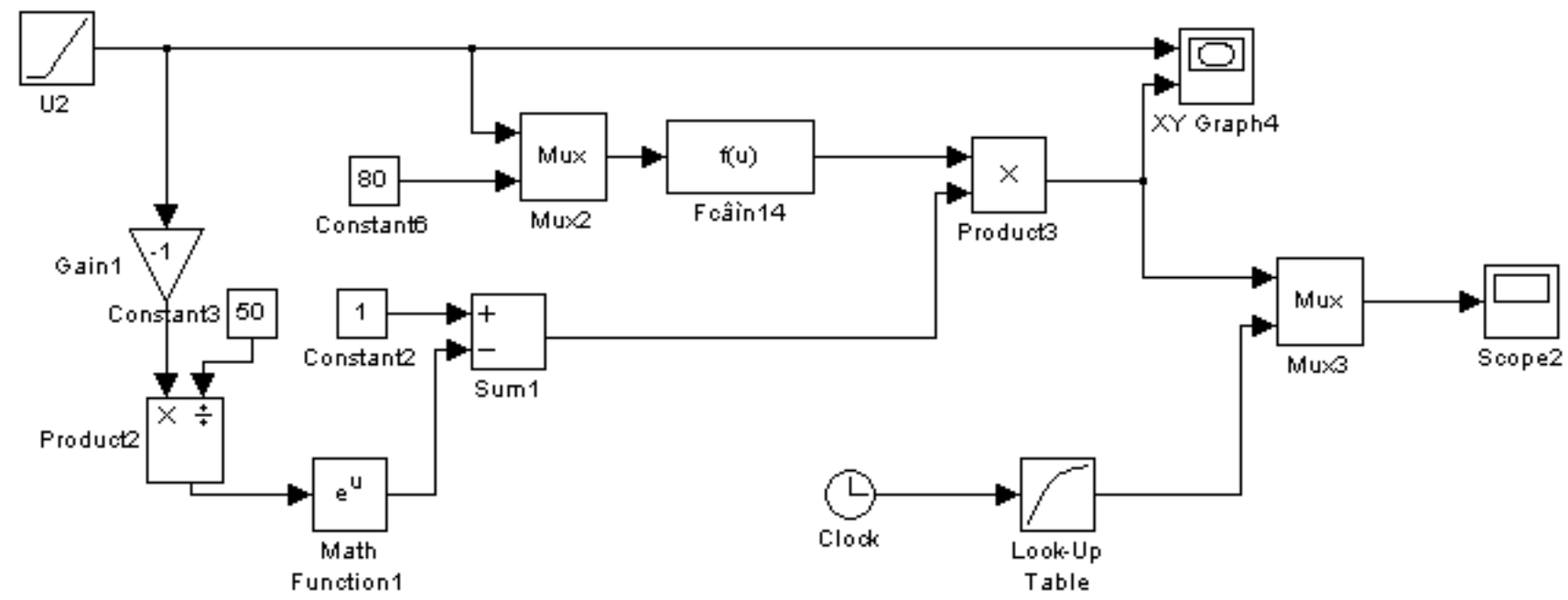

Рис. 2 - реалізація моделі блоку розрахунку тиску на виході випарника

Третя змінна - температура теплоносія на вході в конденсатор. За результатами проведених досліджень зміна температурного режиму конденсатору призводить до суттєвого зсуву статичної залежності тиску холодоагенту на вході компресора від положення клапану ЕРВ $\left(\mathbb{N}_{\mathrm{Kn}}\right)$ та частоти обертання компресора $\left(\mathrm{N}_{\mathrm{K}}\right)$. Залежність величини зсуву від температури води а вході конденсатора має лінійний характер. Динамічні властивості каналів формуються динамічними ланками, передатні функції яких були отримані у [2].

На рисунку 3 представлена реалізація імітаційної моделі ЕРВ у середовищі Simulink. 


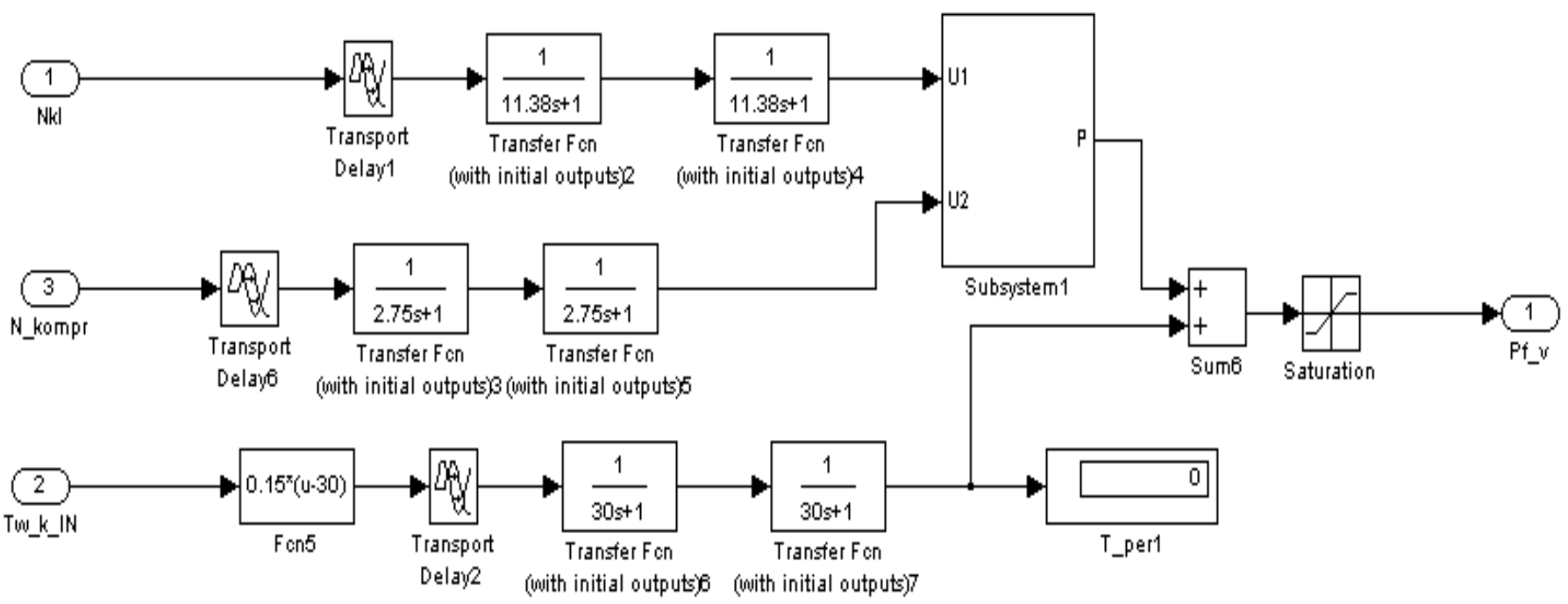

Рис. 3 - реалізація імітаційної моделі ЕРВ у середовищі Simulink

\section{3. Імітаційна модель випарника ТН}

У реальному тепловому насосі через різницю між температурою рідкого холодоагенту до ЕРВ і температурою, що відповідає тиску після ЕРВ, відбувається його часткове випаровування та охолодження до температури, що відповідає тиску на початку випарника (після ЕРВ). При цьому частина холодоагенту, що випаровується, не бере участі в процесі відбору тепла в випарнику і $\epsilon$ «баластовою витратою» $\left(\mathrm{G}_{\mathrm{MB}}\right)$. Тому «ефективна витрата» холодоагенту $\left(\mathrm{G}_{\mathrm{ME}}\right)$, яка бере участь у відборі тепла в випарнику, завжди менше, ніж його загальна витрата через ЕРВ.

$$
G_{M E}=G_{M}-G_{M B}
$$

де $G_{M}$ - загальна масовавитратахолодоагенту крізь ЕРВ;

$G_{M B}$ - баластова витрата холодоагенту (яка не приймає участі у відборі тепла у випарнику).

Баластова витрата холодоагенту розраховується наступним чином:

$$
G_{M B}=\frac{\left(t_{\mathrm{kRT} 1}-t_{\mathrm{kn} 2}\right) \cdot C_{f r} \cdot G_{M}}{L_{\Phi}}
$$

де $t_{\mathrm{kn1},} t_{\mathrm{kn2} 2}$ - температури холодоагенту до та після розширювального вентиля (РВ);

$C_{f y}$ - теплоємність холодоагенту при середній температурі на РВ;

$L_{\emptyset}$ - питома теплота пароутворення при середній температурі на РВ.

Реалізація імітаційної моделі підсистеми розрахунку рівнів «ефективної» $\left(\mathrm{G}_{\mathrm{ME}}\right)$ та «баластової» $\left(\mathrm{G}_{\mathrm{MB}}\right)$ витрат холодоагенту в середовищі Simulink представлена на рисунку 4.

Експериментальні дослідження показали, що залежність втрат тиску (а значить і перепаду температур кипіння) на випарнику від витрати холодоагенту не монотонно зростаюча функція. Вона має екстремум і є спадаючою при роботі випарника в режимах близьких до максимальних завантажень [2, 11, 15]. При зміні величини перегріву парів холодоагенту на виході випарника в діапазоні від 15 до $0{ }^{\circ} \mathrm{C}$ перепад температур його кипіння за довжиною випарника зменшується на кілька градусів., Що істотно впливає на енергетичні показники його роботи і має бути враховано при побудові імітаційної моделі і розробці алгоритмів керування . Тому при створенні імітаційної моделі випарника до неї була додана підсистема розрахунку перепаду температур кипіння (тиску) по довжині випарника в залежності від витрати холодоагенту, що враховує довжину ділянки випарника на якій відбувається кипіння рідкої фази.

Перепад температур кипіння холодоагенту на випарнику розраховується з використання наступної залежності:

$$
\Delta t_{\mathrm{B}}=\left(\frac{G_{E}}{G_{M A X}}-G_{E}^{2}-K_{\mathrm{a}}\right)+\left(\left(1-\frac{G_{E}}{G_{M A X}}\right) \cdot\left(G_{M} \cdot K_{\mathrm{P}}\right)^{2} \cdot K_{4}\right)
$$

де $G_{M A X}-$ максимально можлива витрата холодоагенту при даних умовах*;

$K_{\mathrm{P}}$ - коефіцієнт розширення холодоагенту при випаровуванні;

$K_{\mathrm{a}} K_{4}$ - емпіричні коефіцієнти, які характеризують питомий опір каналу випарника для газу та рідини.

* - витрати холодоагенту при досягненні нульового перегріву парів на виході випарника. 


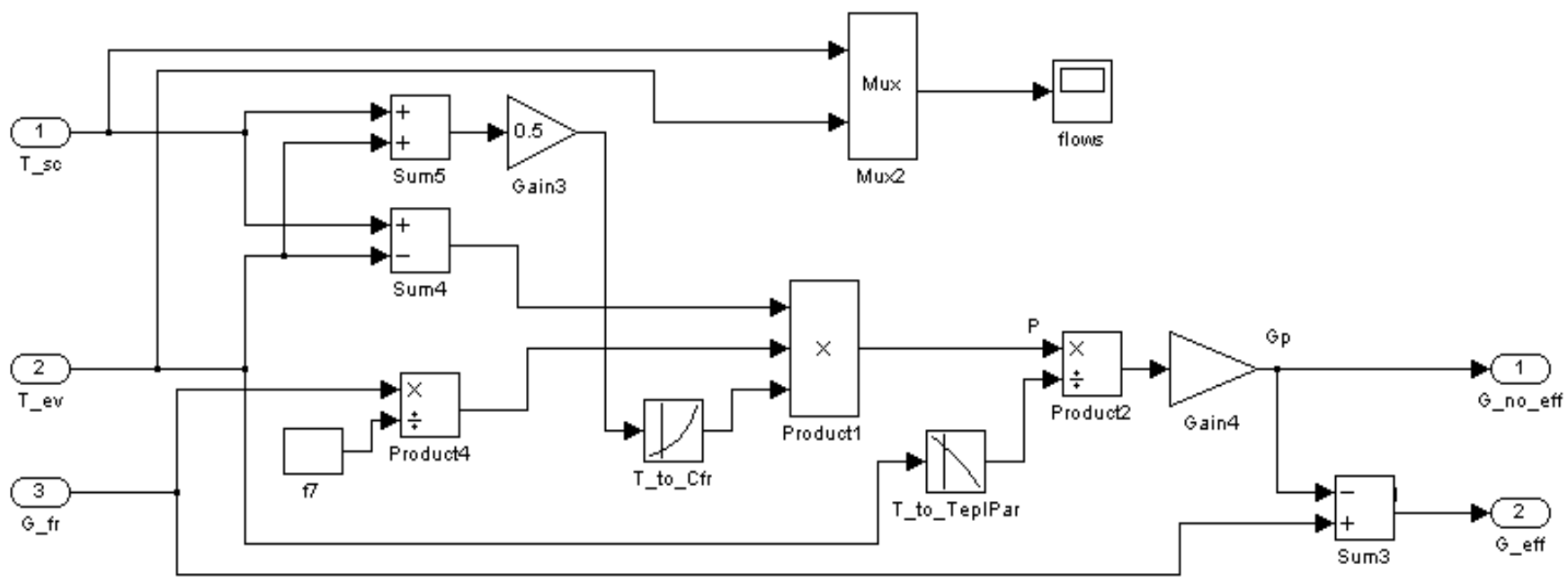

Рис. 4 - Реалізація імітаційної моделі підсистеми розрахунку рівнів «ефективної» $\left(\mathrm{G}_{\mathrm{ME}}\right)$ та «баластової» $\left(\mathrm{G}_{\mathrm{MB}}\right)$ витрат холодоагенту в середовищі Simulink

Тоді температура холодоагенту на вході випарника $\mathrm{t}_{\mathrm{BB} 1}$ (після $\mathrm{EPBt}_{\mathrm{Kл2}}$ ):

$$
t_{\mathrm{BB} 1}=t_{\mathrm{K} 12}=t_{\mathrm{BB} 2}-\Delta t_{\mathrm{B}} \text {. }
$$

Імітаційна модель цієї підсистеми, реалізована у середовищі Simulink,представлена на рисунку 5 А, а результати моделювання при різних температурних напорах в випарнику $(\Delta \mathrm{T} н)$ на рис 5 Б $\left(1-\Delta \mathrm{TH}_{\mathrm{H}}=13{ }^{\circ} \mathrm{C}, 2-\Delta \mathrm{TH}=11{ }^{\circ} \mathrm{C}, 3-\right.$ $\Delta \mathrm{TH}=9{ }^{\circ} \mathrm{C}, 4-$ точки максимально можливої витрати холодоагенту).

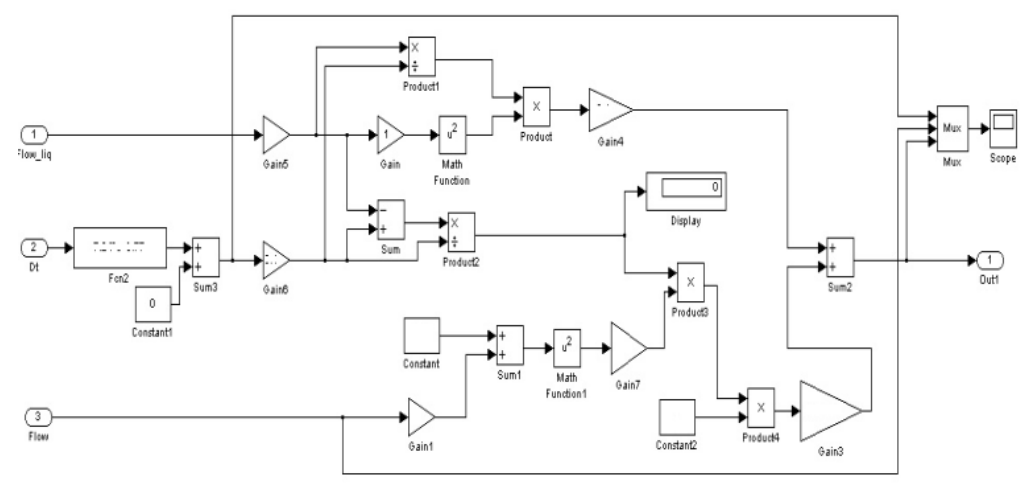

A

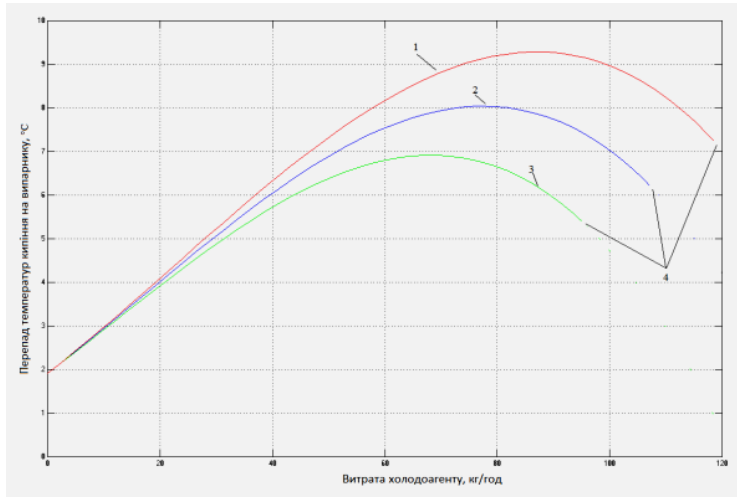

Б

Рис. 5 - Реалізація імітаційної моделі підсистеми розрахунку перепаду температур кипіння холодоагенту у випарнику в середовищі Simulink (A) та результати моделювання при різних температурних напорах в випарнику (Б).

Суттєвий вплив на роботу випарника має температура теплоносія на його вході та його витрата. Ці величини впливають на температурний напір у випарнику і визначають при інших рівних умовах максимально можливе теплове навантаження випарника при наявності перегріву парів холодоагенту на його виході, тобто повному википанні.

Температура теплоносія на виході випарника розраховується за наступним виразом:

де $t_{\mathrm{BB} 1}-$ температура води на вході в випарник;

$$
t_{\mathrm{BB} 2}=t_{\mathrm{BB} 1}-\frac{P_{f y} \cdot K_{\mathrm{BT}}}{G_{\mathrm{BB}} \cdot C_{\mathrm{B}}}
$$

$P_{f y}$ - теплова потужність випарника по холодоагенту;

$K_{\mathrm{BT}}$ - коефіцієнт втрат потужності ( $K_{\mathrm{BT}}=0,9 \ldots 0,97$, залежить від конструкції випарника);

$G_{\mathrm{BB}}-$ витрата води у випарнику;

$C_{\mathrm{B}}$ - теплоємність води.

Теплова потужність випарника по холодоагенту: 
http://www.atbp.onaft.edu.ua/

$$
P_{f y}=G_{M E} \cdot\left(I_{g}-I_{I}\right)
$$

де $I_{g}$ - ентальпія газоподібного холодоагенту на виході випарника;

$I_{l}$ - ентальпія рідкого холодоагенту на вході випарника;

$G_{M E}$ - «ефективна витрата» холодоагенту крізь випарник.

Імітаційна модель випарника включає також динамічні залежності по каналам температури води та холодоагенту на виході випарника, які були ідентифіковані експериментально [2].

Загальна імітаційна модель випарника наведена на рисунку 6.

\section{4. Імітаційна модель компресора}

Імітаційна модель компресора розраховує масову $G_{M}$ витрату холодоагенту та електричну потужність компресора $P_{e l}$. На вході в якості вхідних параметрів моделі використовуються частота обертання двигуна компресора, об'єм одного циліндра компресора, кількість циліндрів компресора, коефіцієнт подачі компресора, тиск холодоагенту на вході компресора (на виході випарника), тиск на виході компресора (на вході в конденсатор), температура холодоагенту на вході компресора. Для спрощення моделі в ній не враховуються динамічні властивості компресора, а статичні залежності розраховуються за наступними виразами.

Об’ємна витрата холодоагенту:

$$
G_{06}=N_{k} \times V_{c y l} \times N_{c y l} \times K_{\mathrm{m}},
$$

де $\mathbb{N}_{k}$ - частота обертання двигуна комперсора;

$V_{c y i}-$ об'єм одного циліндра компресора;

$N_{c y l}$ - кількість циліндрів компресора;

$\mathbb{K}_{\mathrm{m}}$ - коефіціент подачі компресора.

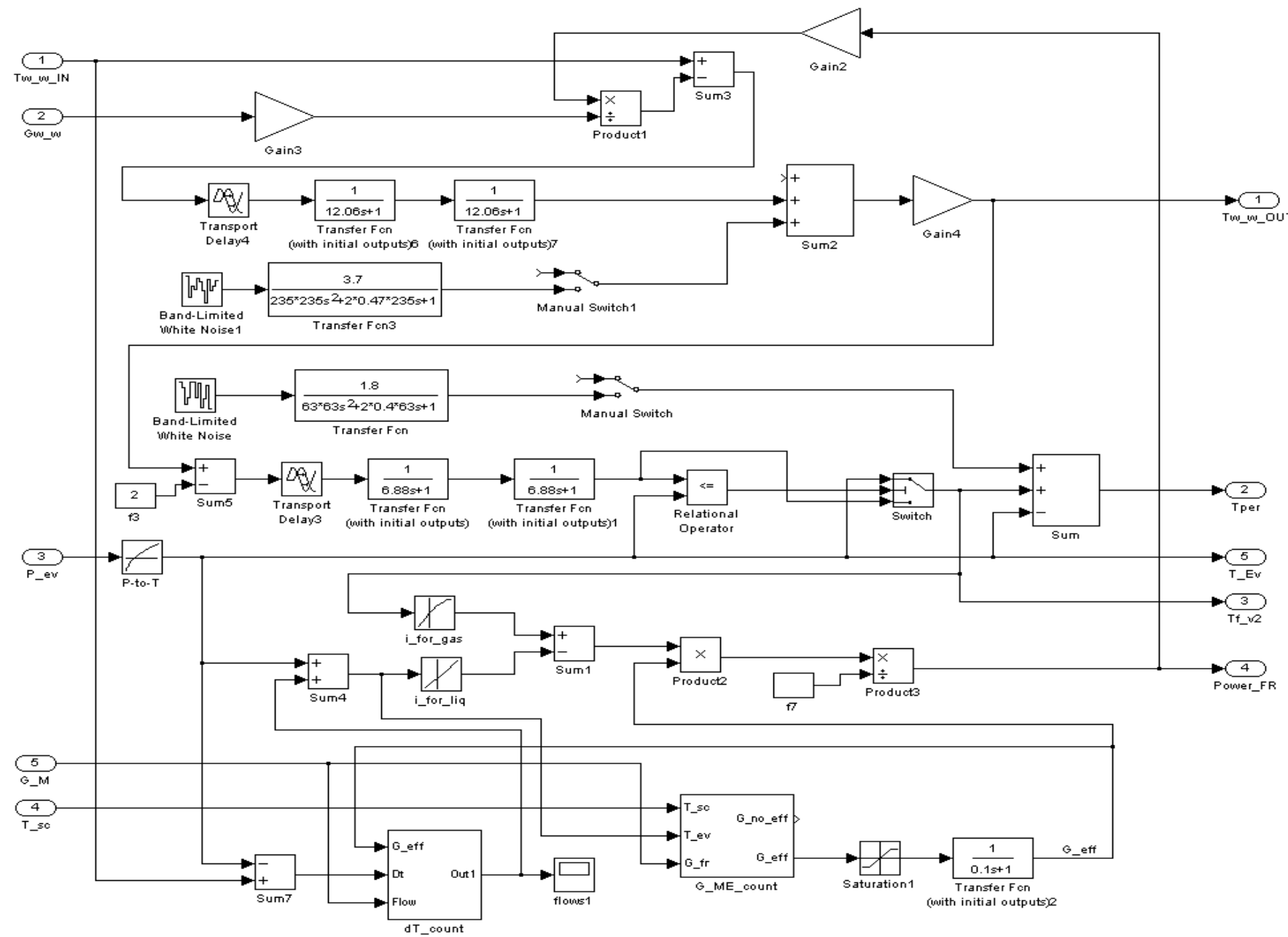

Рис. 6 - Загальнаімітаційна модель випарника 
Коефіцієнт подачі залежить від значення тисків холодоагенту до та після компресора [3]:

де $P_{\mathrm{K}}$ - тиск у конденсаторі;

$$
\mathrm{K}_{\mathrm{I}}=1-\left(\frac{p_{K}}{P_{\mathrm{n}}}, a\right)
$$

$P_{\mathrm{B}}-$ тиск у випарнику;

$a$ - коефіцієнт, який враховує об’ємні втрати, притаманні даному типу компресора (для роторних компресорів а = $(0,03-0,05)$.

Масова витрата холодоагенту $\left(G_{M}\right)[6]$ :

$$
G_{M}=\frac{G_{06} \times P_{\mathrm{B}} \cdot M_{f Y}}{R \cdot T} \cdot K_{\mathrm{K}}
$$

де $P_{\mathbb{E}}$ - тиск холодоагенту на вході компресора;

$M_{f \gamma}$ - молярна маса холодоагенту;

$R$ - універсальна газова постійна;

$T$ - температура перегрітого холодоагенту на вході компресора;

$K_{\mathrm{K}}$ - коригувальний коефіцієнт, враховуючий не ідеальність газу.

Електрична потужність компресора $\left(P_{e \mathbb{I}}\right)$ :

$$
P_{\mathrm{eI}}=\left(\left(P_{\mathrm{K}}-P_{\mathrm{R}}\right) \cdot K_{1}+P_{\mathrm{E}} \cdot K_{2}\right) \cdot \eta_{\mathrm{K}}
$$

де $P_{\mathrm{K}}$ - тиск холодоагенту на виході компресора;

$P_{\mathrm{E}}$ - тиск холодоагенту на вході компресора;

$K_{1}, K_{2}$ - емпіричні коефіцієнти (залежать від типу компресора);

$\eta_{\mathrm{K}}=f\left(N_{K}\right)-$ ККД електропривода (залежить від частоти обертання компресора та типу електропривода).

Реалізація блоку розрахунку електричної потужності компресора та загальної моделі компресора в середовищі Simulink наведена на рисунках 7 та 8 відповідно.

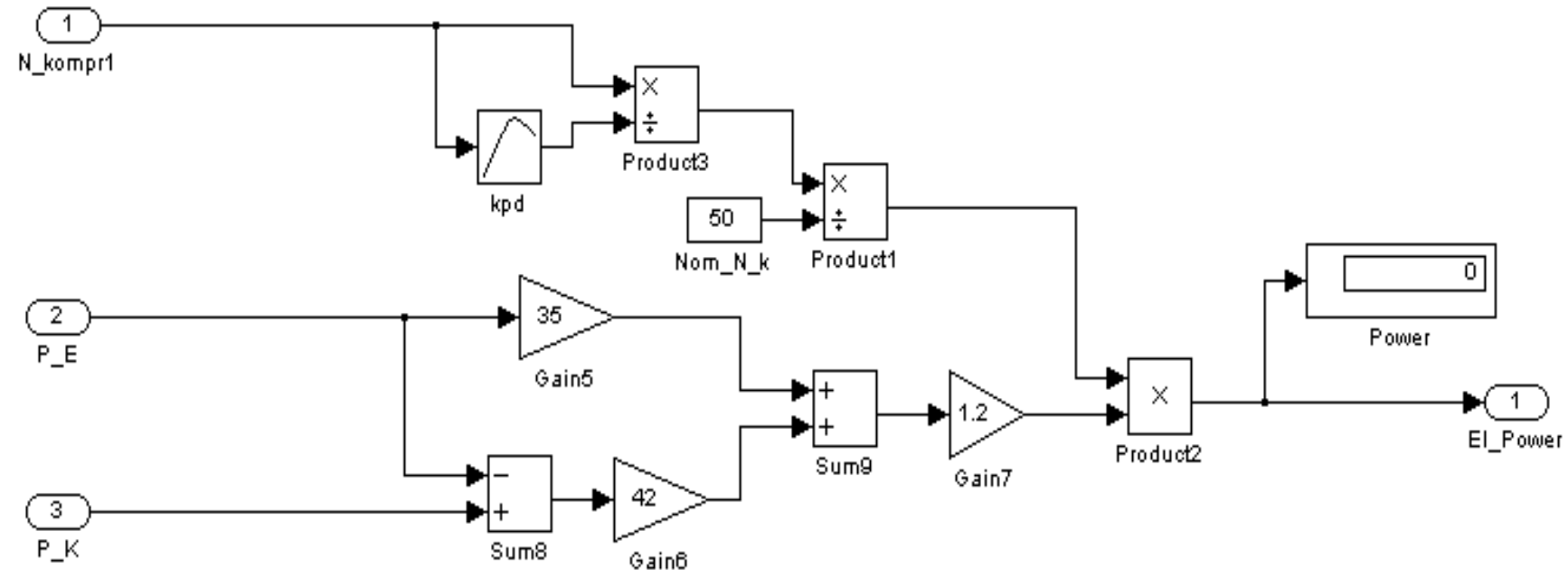

Рис. 7 - Реалізація блоку розрахунку електричної потужності компресора 


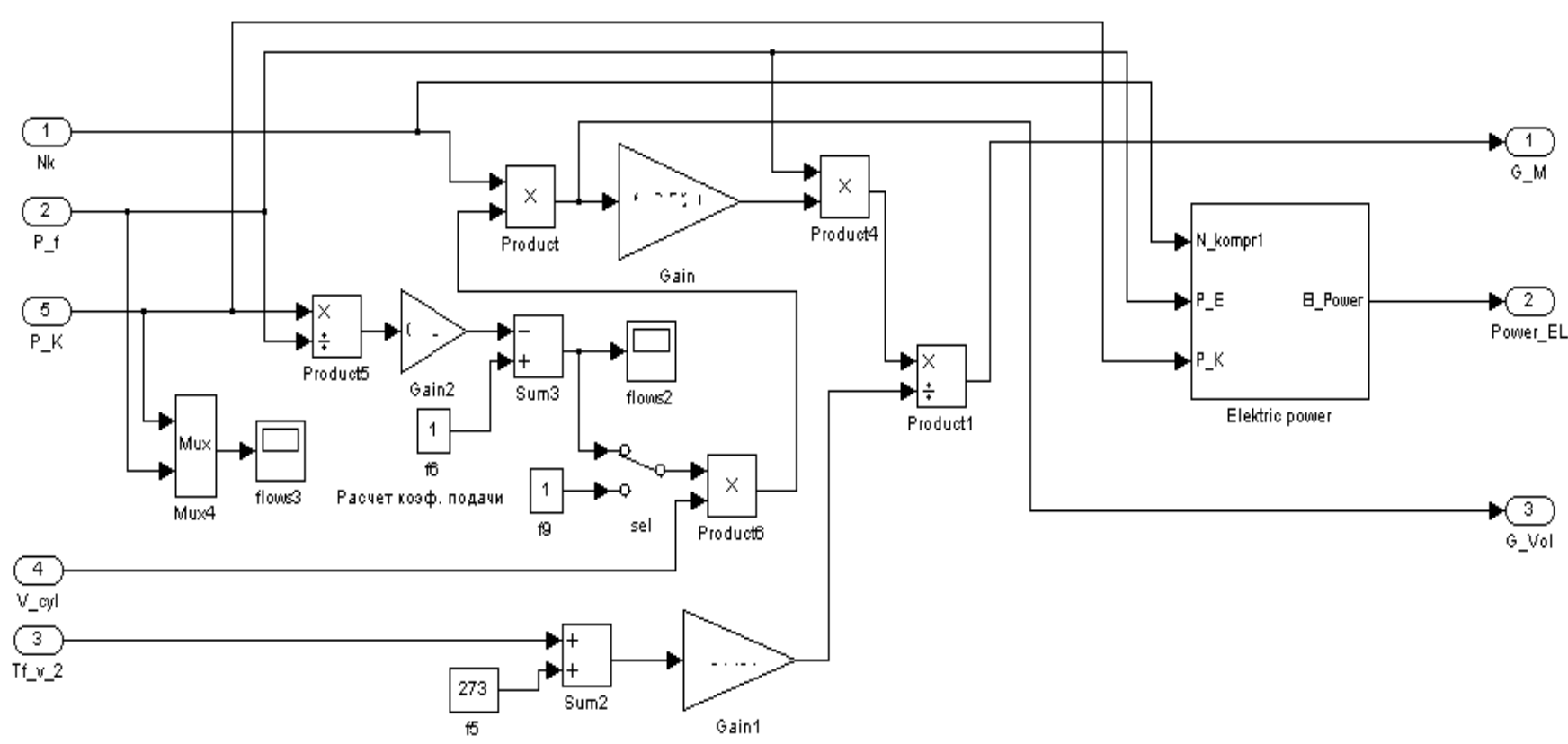

Рис. 8 - Загальна імітаційна модель компрессора

\section{5. Імітаційна модель конденсатора}

Вхідними параметрами моделі є теплова потужність випарника $\left(P_{f y}\right)$, електрична потужність компресора $\left(P_{e \mathbb{l}}\right)$, температура $\left(t_{\mathrm{BK} 1}\right)$ та витрата води крізь конденсатор $\left(G_{\mathrm{BK}}\right)$. Розглядаючи конденсатор як об'єкт 3 зосередженими параметрами та виходячи 3 того, що у системі в статичних режимах підтримуються тепловий та енергетичний баланси, можна розрахувати теплову потужність $\left(P_{k}\right)$, яка виділяється на конденсаторі як суму потужностей випарника та компресора з урахуванням втрат в навколишнє середовище:

$$
P_{k}=\left(P_{f y}+P_{\mathrm{el}} \cdot K_{\mathrm{BTE}}\right)
$$

де $P_{f y}-$ теплова потужність випарника по холодоагенту;

$P_{\text {घl }}$ - електрична потужність споживана компресором;

$K_{\text {вте }}-$ коефіцієнт втрат теплової потужності на двигуні

Тоді температура води на виході конденсатора $\left(t_{\mathrm{BK} 2}\right)$ :

$$
t_{\mathrm{BK} 2}=t_{\mathrm{BK} 1}+\frac{P_{k} \cdot K_{\mathrm{BTK}}}{G_{\mathrm{BK}} \cdot C_{\mathrm{B}}}
$$

де $t_{\mathrm{BK1}}-$ температура води на вході в конденсатор;

$K_{\text {втк }}-$ коефіцієнт втрат теплової потужності на конденсаторі;

$G_{\mathrm{BK}}-$ витрата води крізь конденсатор;

$C_{\mathrm{B}}$ - теплоємність води.

Температура конденсації холодоагенту $\left(t_{\mathrm{Kg}}\right)$ залежить від температури води на виході конденсатора та щільності теплового потоку крізь нього, яка в свою чергу залежить від потужності, що виділяється на конденсаторі та його конструкції [1]:

$$
t_{\mathrm{KM}}=t_{\mathrm{BK} 2}+\left(P_{f r}+P_{\mathrm{el}}\right) \cdot \mathrm{K}_{5}
$$

де $\mathrm{K}_{5}$ - емпіричний коефіцієнт, який залежить від конструкції конденсатора.

Температура холодоагенту на виході конденсатора $\left(t_{\oplus \mathrm{K} 2}\right)$ :

$$
t_{\Phi \mathrm{K} 2}=t_{\mathrm{BK} 1}+\left(P_{f Y}+P_{e 1}\right) \cdot \mathrm{K}_{6}
$$

де $\mathrm{K}_{6}$ - емпіричний коефіцієнт, який залежить від конструкції конденсатора.

Динамічні властивості каналів описуються ланками, передатні функції яких були отримані у [2].

На рисунку 9 представлена реалізація імітаційної моделі конденсатора у середовищі Simulnk. 


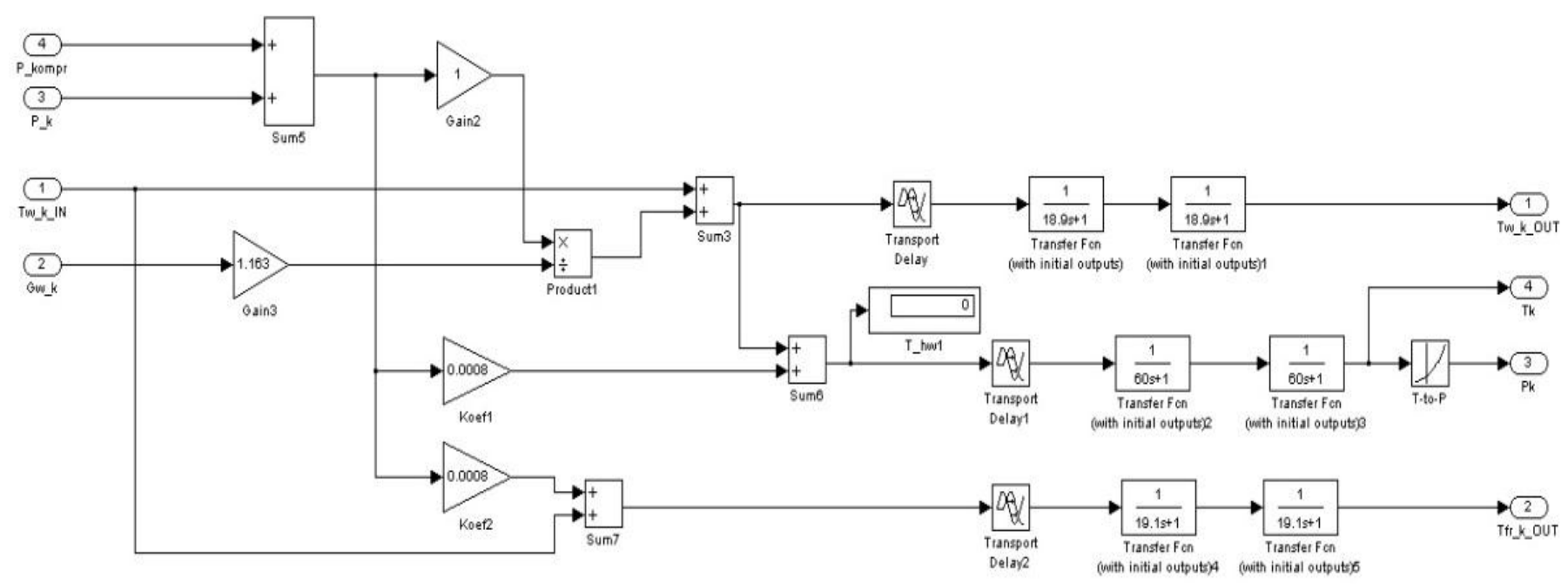

Рис. 9 - реалізація імітаційної моделі конденсатора у середовищі Simulnk

\section{6. Імітаційна модель переохолоджувача}

Вхідними параметрами моделі $\epsilon$ температура $\left(t_{\mathrm{B \Pi 1}}\right)$ та витрата $\left(G_{\mathrm{B \Pi}}\right)$ води крізь переохолоджувач, а також температура $\left(t_{\oplus \Pi 1}\right)$ та витрата $\left(G_{M}\right)$ холодоагенту крізь нього. Переохолоджувач також розглядається як об'єкт 3 зосередженими параметрами. Потужність, що виділяється на переохолоджувачі рідкого холодоагенту $\left(P_{\Pi}\right)$ розраховється за наступною залежністю:

$$
P_{\Pi}=G_{M} \cdot\left(I_{i 1}-I_{12}\right),
$$

де $I_{11}$ та $I_{12}$ - ентальпії рідкого холодоагенту на вході і виході переохолоджувача відповідно;

Температура води на виході переохолоджувача рідкого холодоагенту $\left(t_{\mathrm{B \Pi z}}\right)$ :

де $t_{\mathrm{B \Pi 1}}$ - температура води на вході в переохолоджувач;

$$
t_{\mathrm{B} \Pi 2}=t_{\mathrm{B \Pi} 1}+\frac{p_{\Pi}}{G_{\mathrm{E}} \cdot C_{\mathrm{B}}},
$$

$P_{\Pi}$ - теплова потужність переохолоджувача;

$G_{\mathrm{B}}-$ витрата води через переохолоджувач.

Температура холодоагенту на виході переохолоджувача $\left(t_{\Phi П 2}\right)$;

$$
t_{\Phi \Pi 2}=t_{\mathrm{B \Pi} 1}+P_{\Pi 1} \cdot K_{7},
$$

де $t_{\text {ВП1 }}$ - температура води на вході переохолоджувача;

$P_{\Pi}$ - теплова потужність переохолоджувача;

$K_{7}$ - емпіричний коефіцієнт, який залежить від конструкції.

Динамічні властивості каналів описуються ланками, передатні функції яких були отримані у [2].

Реалізація імітаційної моделі переохолоджувача у середовищі Simulink представлена на рисунку 10.

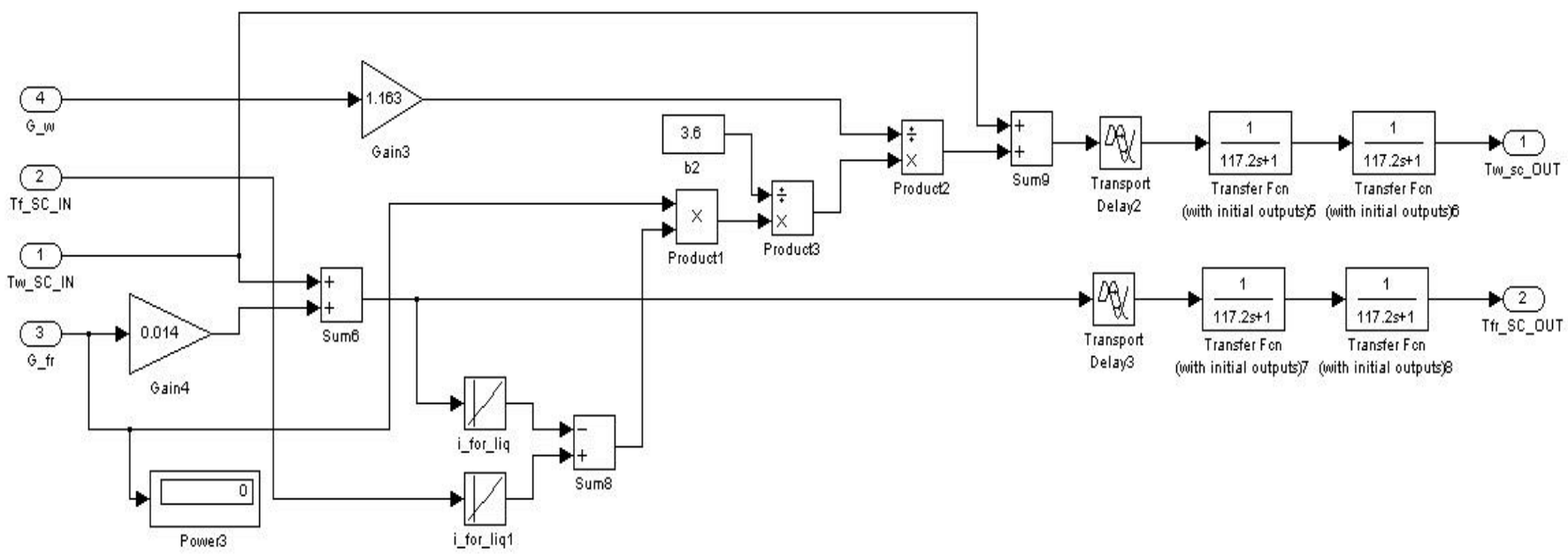

Рис. 10 - реалізація імітаційної моделі переохолоджувача у середовищі Simulink 


\section{7. Імітаційна модель контактного теплообмінника-утилізатора тепла ППС}

Вхідними параметрами моделі є температура $\left(t_{\mathrm{BTY1}}\right)$ та витрата $\left(G_{\mathrm{BTy}}\right)$ охолоджуючої води, а також температура $\left(t_{\Pi \Pi C_{1}}\right)$, витрата $\left(G_{\Pi п c}\right)$ та вологовміст $\left(f_{1}\right)$ ППС. В моделі контактний теплообмінник-утилізатор $(T У)$ ППС, також розглядається як об'єкт з зосередженими параметрами. Витрати охолоджуючої води через ТУ прийняті сталими i керування потужністю здійснюється за рахунок зміни її температури.

Експериментальні дослідження показали, що залежність температури ППС на виході ТУ від температури води на його вході з достатнім ступенем достовірності можна описати лінійним рівнянням[12]:

$$
t_{\mathrm{M \Pi C2}}=t_{\mathrm{BTY} 1} \cdot K_{\mathrm{g}}+b
$$

де $t_{\mathrm{BTY} 1}$ - температура води на вході в теплоутилізатор;

$K_{g}, b-$ емпіричні коефіцієнти, які залежать від конструкції ТУ.

Теплова потужність, яка відбирається від ППС $\left(P_{\text {TY }}\right)$ складається з чотирьох частин [12]: потужності охолодження

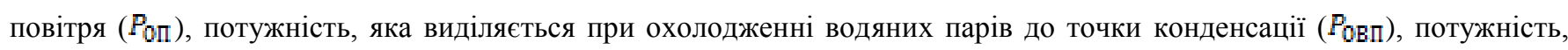
яка виділяється при конденсації водяних парів $\left(P_{\mathrm{Kn}}\right)$,потужність, яка виділяється при переохолодженні конденсату до температури води на виході ТУ $\left(P_{\mathbb{\Pi K}}\right)$.

$$
\begin{aligned}
& P_{\mathrm{TY}}=P_{0 \mathrm{O}}+P_{0 \mathrm{B \Pi}}+P_{\mathrm{KM}}+P_{\mathrm{IK}}
\end{aligned}
$$

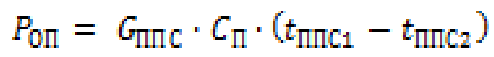

$$
\begin{aligned}
& P_{\mathrm{OB \Pi}}=f_{1} \cdot G_{\mathrm{MICC}} \cdot \mathrm{C}_{\mathrm{B}}\left(t_{\mathrm{M \Pi C} 1}-t_{\mathrm{Kc}}\right) \\
& P_{\mathrm{KM}}=\left(f_{1}-f_{2}\right) \cdot G_{\mathrm{IIIC}} \cdot L_{\mathrm{E}} \\
& P_{\mathrm{MK}}=\left(f_{1}-f_{2}\right) \cdot G_{\Pi \Pi \mathrm{C}} \cdot \mathrm{C}_{\mathrm{B}} \cdot\left(t_{\mathrm{Kc}}-t_{\mathrm{BTY2}}\right)
\end{aligned}
$$

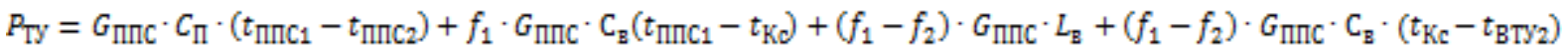

Де: $f_{1}$-абсолютний вологовміст ППС при температурі $t_{\text {ппс1 }}$;

$f_{2}$ - максимально можливий абсолютний вологовміст ППС виході ТУ при температурі $t_{\Pi п{ }_{2}}$;

Gпп - витрата ППС через ТУ;

$C_{\text {П }}$ - теплоємність повітря;

$t_{\text {Ппс1 }}$ - температура ППС на вході в ТУ;

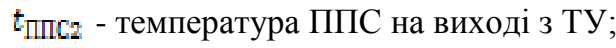

$L_{\mathrm{g}}$ - питома теплота пароутворення води при середній температурі конденсації.

Температура води на виході теплоутилізатора $\left(t_{\mathrm{BTY} 2}\right)$;

$$
t_{\mathrm{BTY} 2}=t_{\mathrm{BTY} 1}+\frac{P_{\mathrm{TY}} \cdot K_{\mathrm{BTxy}}}{G_{\mathrm{BTy}} \cdot C_{\mathrm{B}}}
$$

де: $t_{\mathrm{BTY} 1}$ - температура води на вході в теплоутилізатор;

$P_{\text {Ty }}$ - теплова потужність теплоутилізатора;

$K_{\text {втту }}$ - коефіціент втрат потужності на теплоутилізаторі;

$G_{\mathrm{BTy}}$ - витрата води через теплоутилізатор.

Динамічні властивості каналів описуються ланками, передатні функції яких були отримані у [2].

Реалізація імітаційної моделі теплоутилізатора в середовищі Simulink представлена на рисунку 11.

\section{8. Складання загальної імітаційної моделі}

На рисунку 12 представлена реалізація загальної імітаційної моделі процеса УТПВС з використанням ТН в середовищі Simlink. До складу моделі в якості підсистем входять моделі розглянуті вище. 


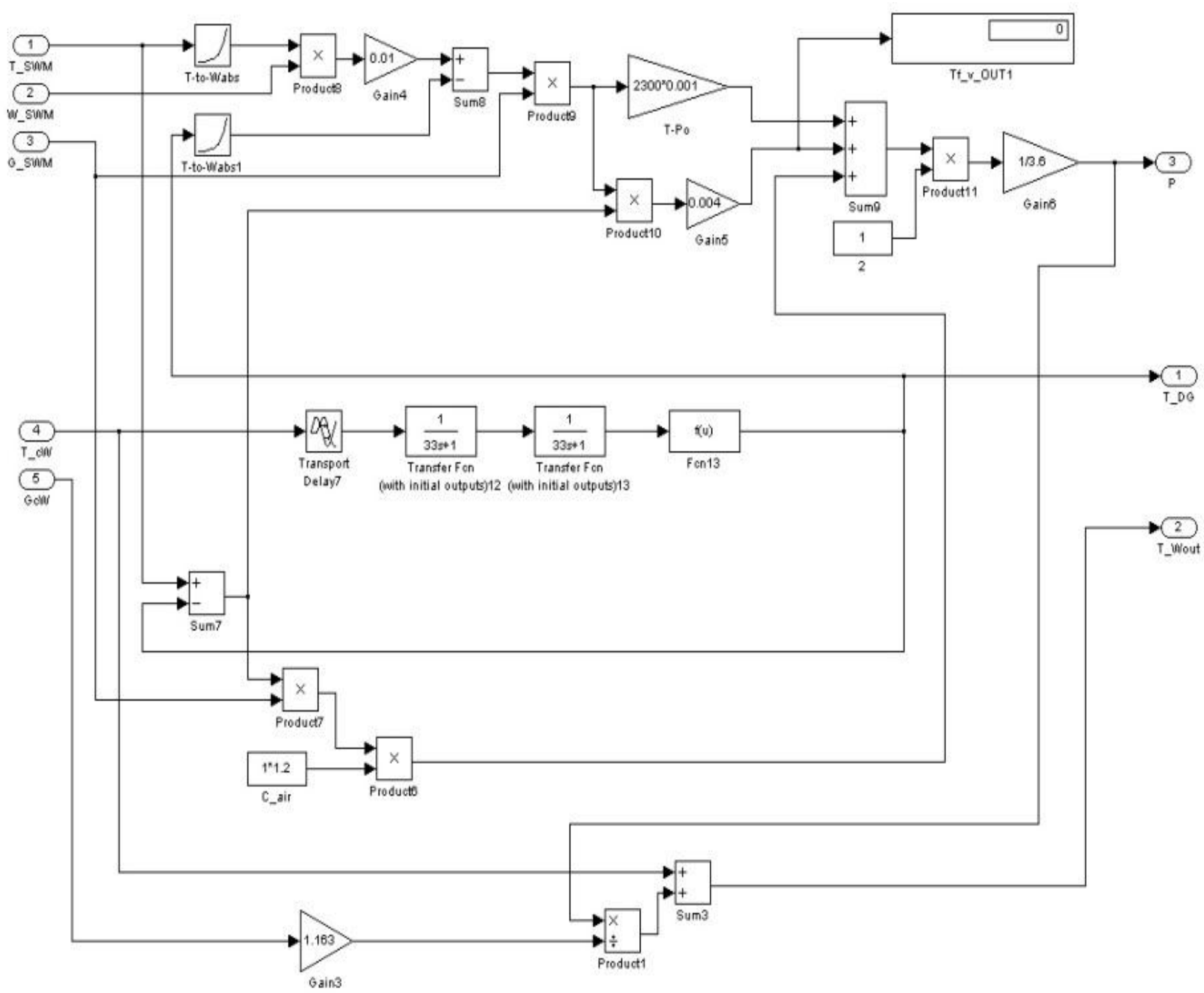

Рис. 11 - реалізація імітаційної моделі теплоутилізатора в середовищі Simulink

\section{3. Перевірка моделі на адекватність}

Для перевірки моделі на адекватність було проведено ряд комп'ютерних експериментів та отримані квазістатичні та динамічні залежності по основним каналам перетворення.

На рисунку 13 А представлене сімейство отриманих в результаті проведення експерименту та при моделюванні квазістатичних залежностей тиску у випарнику від положення ЕРВ при різних частотах обертання компресора (1 - 45 об/c, 2 - 50 об/c, 3 - 55 об/с, 4 - 60 об/c), а на рисунку 13 Б - при різних температурах води на вході конденсатора (1 $\left.45^{\circ} \mathrm{C} 2-40^{\circ} \mathrm{C}, 3-35^{\circ} \mathrm{C}, 4-30^{\circ} \mathrm{C}\right)$

На рисунку 13 В представлене сімейство отриманих в результаті проведення експерименту та при моделюванні квазістатичних залежностей тиску у випарнику від частоти обертання компресора при різних положеннях ЕРВ $(1-300$ кр, 2 - 350 кр, 3 - 400 кр, 4 - 450 кр), а на рисунку 13 Г - при різних температурах води на вході конденсатора $\left(1-45^{\circ} \mathrm{C}\right.$ $\left.2-40^{\circ} \mathrm{C}, 3-35^{\circ} \mathrm{C}, 4-30^{\circ} \mathrm{C}\right)$.

На рисунку 14 А представлені результати моделювання перехідного процесу при ступінчастій зміні частоти обертання компресора 340 до 60 об/с. На рисунку: 1 - температура кипіння, 2 - тиск у випарнику, 3 - температура перегріву холодоагенту.

На рисунку 14 Б представлені результати моделювання динамічних властивостей при ступінчастій зміні положення ЕРВ з 400 до 500 кроків. На рисунку: 1 - температура кипіння, 2 - тиск у випарнику, 3 - температура перегріву холодоагенту. 


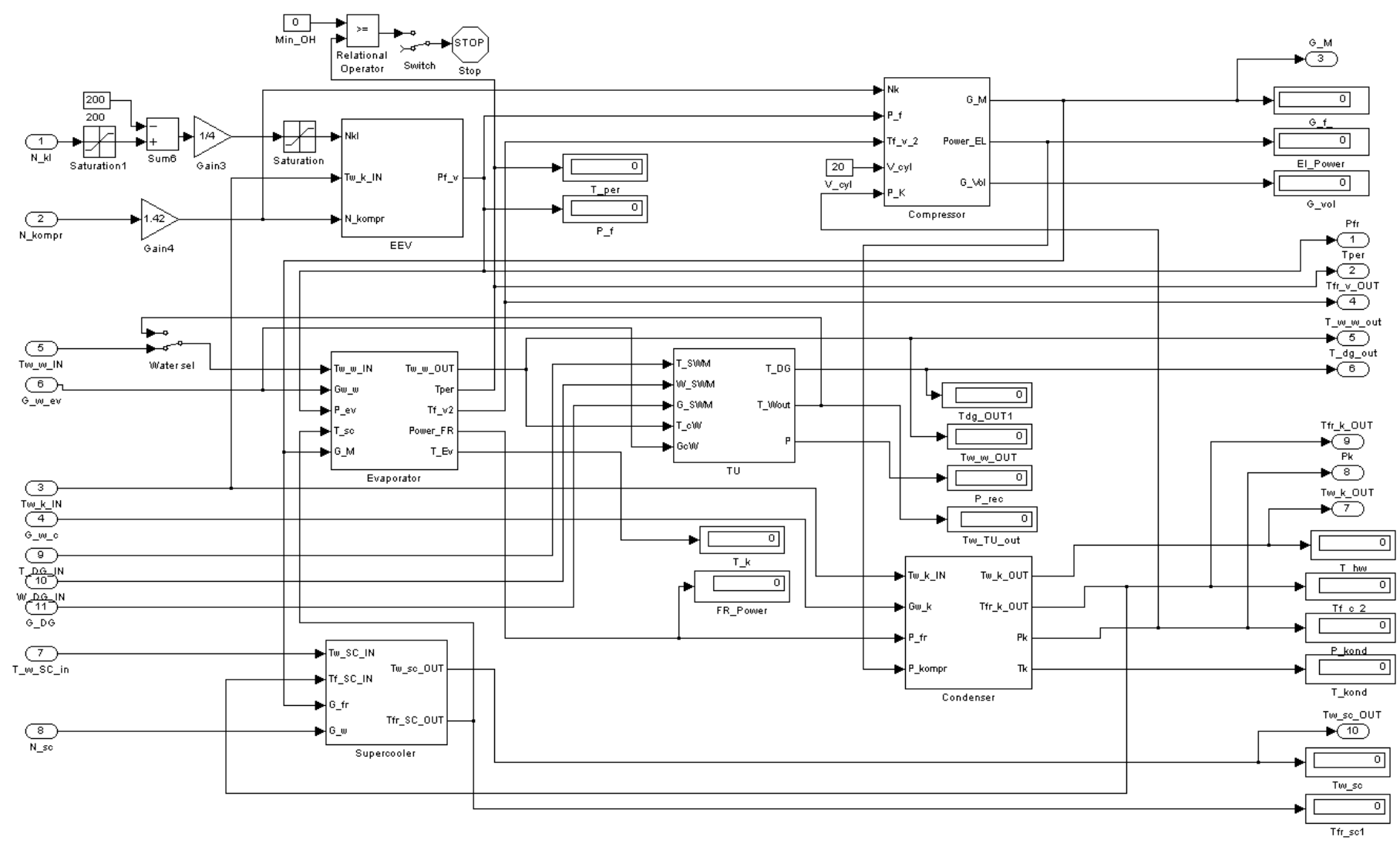

Рис. 12 - реалізація загальної імітаційної моделі процеса УТПВС з використанням ТН в середовищі Simlink

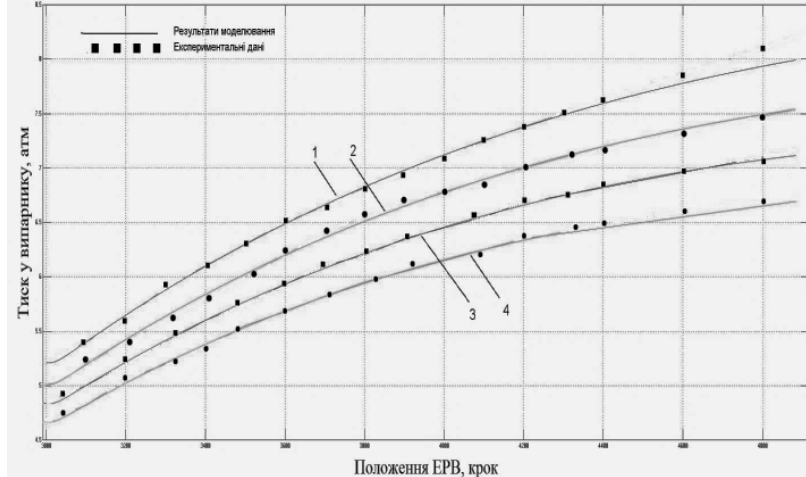

A)

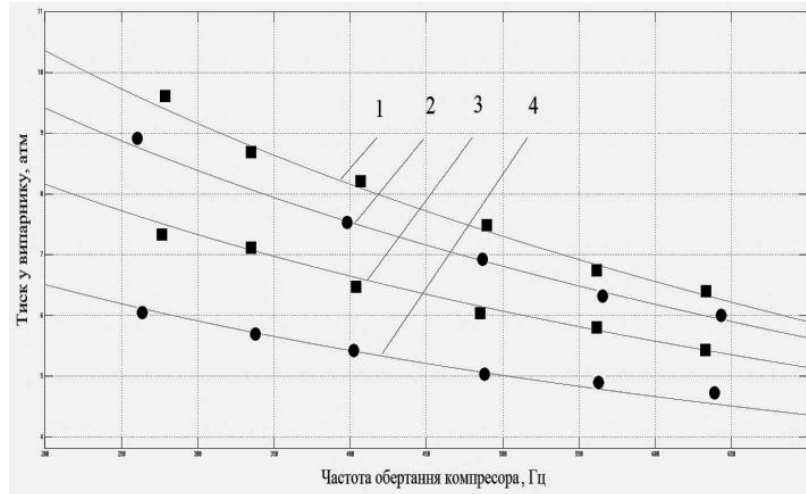

B)

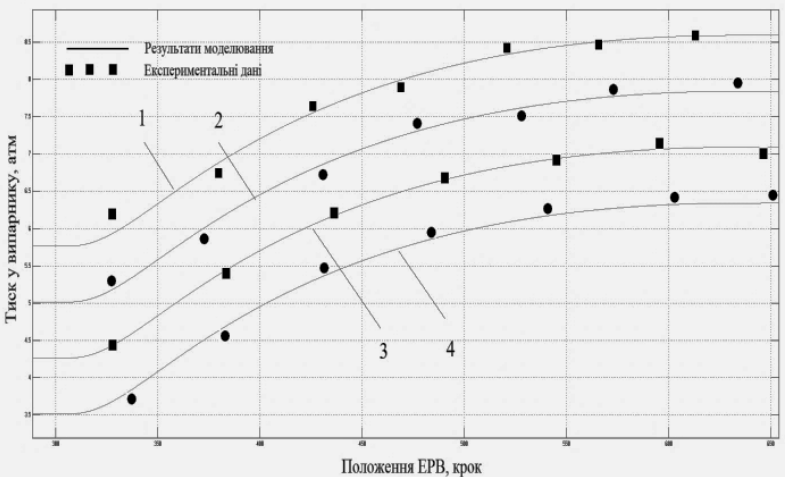

Б)

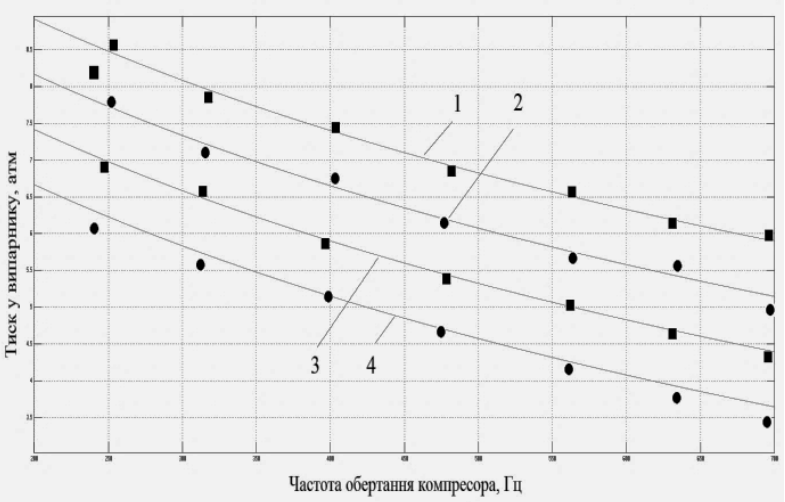

Г)

Рис. 13 - порівняння експериментальних даних та результатів моделювання статичних характеристик 

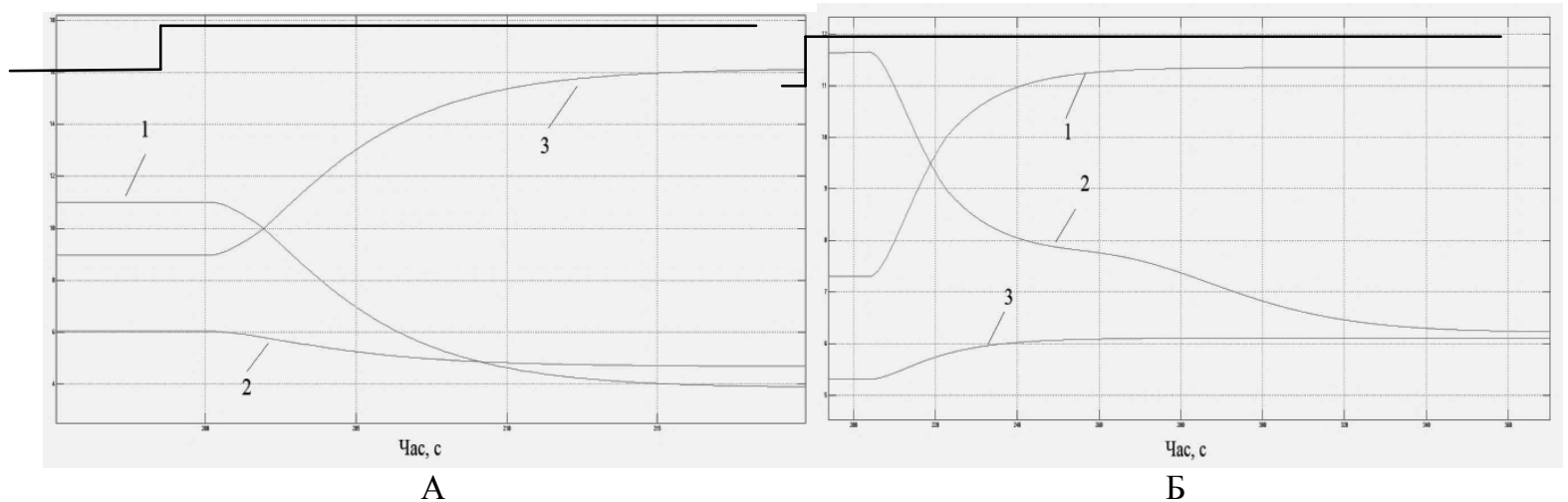

Рис. 14 - порівняння експериментальних даних та результатів моделювання динамічних характеристик

Представлені результати досліджень свідчать про те, що розроблену імітаційну модель можна вважати адекватною, оскільки вона досить точно відтворює процеси, які протікають в реальній системи УТПВС 3 використанням ТН.

\section{4. Висновки}

В результаті виконаної роботи була розроблена імітаційна модель процесу утилізації тепла ПВС з використанням теплового насосу. До складу імітаційної моделі процесу УТППС входять імітаційні моделі компресора, конденсатора, електронного розширювального вентиля, випарника, переохолоджувача та контактного теплообмінника - утилізатора тепла пароповітряних сумішей. Імітаційні моделі цих складових побудовані з використанням експериментальних даних, отриманих авторами в результаті виконання фізичних натурних експериментів на лабораторній дослідній установці.

Модель досить точно відтворює фізичні властивості реальної системи, про що свідчить перевірка їі на адекватність і може бути використаною при розробці енергоефективних алгоритмів керування процесом УТППС з використанням ТН а також для оцінки рівня ефективності використання утилізації тепла ППС для конкретних умов.

В імітаційній моделі випарника теплового насосу реалізовано функцію розрахунку «баластної» та «ефективної» витрати холодоагенту. «Баластна» витрата виникає за рахунок переохолодження холодоагенту до температури кипіння і супроводжується випаровуванням його частки, яка не приймає участі у відборі тепла випарником. Для цього до імітаційної моделі випарника була додана підсистема розрахунку перепаду температур кипіння (тиску) по довжині випарника в залежності від витрати холодоагенту та температурного напору у випарнику, що враховує довжину ділянки випарника на якій відбувається кипіння рідкої фази. Залежність перепаду температури (тиску) кипіння по довжині випарника від витрат холодоагенту через нього є не монотонно зростаючою функцією а має екстремум і спадає при рівнях перегрівах холодоагенту від 15 до $0{ }^{\circ} \mathrm{C}$ на декілька градусів. Тиск на виході випарника розраховується в моделі з використанням нелінійної функції двох змінних - положення клапана ЕРВ та частоти обертання компресора. Динамічні властивості каналів описуються ланками, передатні функції яких були отримані в результаті фізичних експериментів.

Порівняння результатів моделювання та фізичного експерименту показало високу ступінь їх схожості.

\section{Список використаних джерел}

[1] Ковальчук Д. А., Мазур О. В., Гудзь С. С. Дослідження процесів утилізації тепла пароповітряних сумішей: лабораторна установка, вимірювані змінні, автоматизація експериментів //Automation of technological and business processes. -2018 . - T. 10. - №. 2 .

[2] Ковальчук Д. А., Мазур О. В., Хобін В. А. Дослідження процесів утилізації тепла пароповітряних сумішей: результати експериментів, структурна та параметрична ідентифікація основних каналів об'єкту //Automation of technological and business processes. - 2019. - Т. 11. - №. 1.

[3] Карелин Д. Л. Динамическая модель парокомпрессионной системы охлаждения энергетических машин. Вестник ТюмГУ: Физико-математическое моделирование. Нефть, газ, энергетика. 2018. Том 4№ 2.

[4] Розенфельд, Л. М., Ткачев, А. Г. Холодильные машины и аппараты. Госторгиздат, Москва, ГИТЛ, 1960,666 с.

[5] Kovalchuk D., Mazur A., Hudz S. The model for power efficiency assessment of condensation heating installations //Автоматизація технологічних та бізнес-процесів. - 2017. - Т. 9. - №. 3.

[6] Касаткин, А. Г. Основные процессы и аппараты химической промышленности. М.: Госхимиздат, 1971.

[7] Ефимов, А. В., Гончаренко, А. Л. Математическая модель системы "котел-теплоутилизатор"// Вестник Национального технического университета Харьковский политехнический институт. Серия: Информатика и моделирование. 2010. №21. C. 76-87. http://library.kpi.kharkov.ua/files/Vestniki/2010_21.pdf

[8] Jin, Hui, and Jeffrey D. Spitler. "A parameter estimation based model of water-to-water heat pumps for use in energy calculation programs." ASHRAE transactions 108 (2002): 3.

[9] Чемеков, В. В. (2012). Построение математической модели системы автономного теплоснабжения на базе теплового насоса. Научно-технические ведомости СПбПУ. Естественные и инженерные науки, (2-2 (147)).

[10] Казаков, В. Г., Луканин, П. В., \& Смирнова, О. С. (2011). Термодинамические методы анализа в энергоиспользующих процессах: учебное пособие. СПб ГТУРП. СПб., 2011, 93 с. 
[11] Ейдеюс А. И., Кошелев С. В., Никишин М. Ю. Теплоотдача и падение давления при кипении хладагентов в змеевиках // Вестник Международной академии холода. 2016. № 2. С. 42-47.

[12] Кудинов, А. А. Энергосбережение в теплогенерирующих установках. Ульяновск: УлГТУ, 2000. 139 с.

[13] Кишкин, А. А., Лавров, Н. А., Делков, А. В., Мокеев, В. В. (2012). Моделирование режимов работы малых холодильных установок. Инженерный журнал: наука и инновации, 5 (5). 91-98 DOI: 10.18698/2308-6033-2012-5187

[14] Шешунова, Е. В., \& Зиновьев, К. А. (2017). Математическое моделирование работы теплового насоса. Вестник АПК Верхневолжья, (1), 73-78.

[15] Малышев, А. А., Мамченко, В. О., Мизин, В. М., Потанина, А. В., Прошин, С. И., Девятов, Т. И. (2013). Перспективные типы испарителей холодильных машин. Вестник Международной академии холода, (2). С. 13-18

[16] Иваняков, С. В., Коныгин, С. Б. Гидродинамика насадочных аппаратов. Самара; Самар. гос. техн. ун-т, 2008.44 c.

[17] Кулагин, В. А., Пьяных, Т. А. (2013). Расчет режимных параметров суперкавитационного испарителя. In TA Пьяных//Research Journal of International Studies: cб. по результатам ХVIII заочной научной конференции.Екатеринбург: ООО «Европринт (pp. 56-59).

[18] Kandlikar, S. G. (1990). A general correlation for saturated two-phase flow boiling heat transfer inside horizontal and vertical tubes.

[19] Компрессоры холодильные объемного действия: методы испытания [Електронний ресурс]. - 2005. - Режим доступу: https://files.stroyinf.ru/Data2/1/4294826/4294826223.htm. (Дата зверення: 11.11.2019)

\section{References}

[1] Kovalchuk, D. A., Mazur, O. V., Gudz, S. S. Doslidzhennya protsesiv utilizatsiyi tepla paropovitryanih sumishey: laboratorna ustanovka, vimiryuvani zminni, avtomatizatsiya eksperimentiv. Automation of technological and business processes, 2018, Vol. 10, No. 2, pp. 64-72. Doi: https://doi.org/10.15673/atbp.v10i2.981

[2] Kovalchuk, D. A., Mazur, O. V., Hobin, V. A. A research of steam-air mixtures heat utilization processes: experiment results, structural and parametric identification of the object main channels. Automation of technological and business processes, 2019, Vol. 11, No. 1, pp. 32-42. Doi: https://doi.org/10.15673/atbp.v11i1.1327

[3] Karelin, D. L. Dinamicheskaya model parokompressionnoi sistemyi ohlazhdeniya energeticheskih mashin. Vestnik TyumGU: Fiziko-matematicheskoe modelirovanie. Neft, gaz, energetika, 2018, Vol. 4, No. 2.

[4] Rozenfeld, L. M., Tkachev, A. G. Holodilnyie mashinyi i apparatyi. Gostorgizdat, Moskva, GITL, 1960,666 p.

[5] Kovalchuk, D., Mazur, A., Hudz, S. The model for power efficiency assessment of condensation heating installations. Automation of technological and business processes, 2017, Vol. 9, No. 3, pp. 13-19. DOI https://doi.org/10.15673/atbp.v9i3.715

[6] Kasatkin, A. G. Osnovnyie protsessyi i apparatyi himicheskoy promyishlennosti. M.: Goshimizdat, 1971.

[7] Efimov, A. V., Goncharenko, A. L. Matematicheskaya model sistemyi "kotel-teploutilizator". Vestnik natsionalnogo tehnicheskogo universiteta "Harkovskiy politehnicheskiy institut". Seriya: Informatika i modelirovanie, 2010, No. 21, pp. 76-87. http://library.kpi.kharkov.ua/files/Vestniki/2010_21.pdf

[8] Jin, Hui, Jeffrey D. Spitler. A parameter estimation based model of water-to-water heat pumps for use in energy calculation programs. ASHRAE transactions 108 (2002): 3.

[9] Chemekov, V. V. (2012). Postroenie matematicheskoy modeli sistemyi avtonomnogo teplosnabzheniya na baze teplovogo nasosa. Nauchno-tehnicheskie vedomosti SPbPU. Estestvennyie i inzhenernyie nauki, 2-2 (147).

[10] Kazakov, V. G., Lukanin, P. V., Smirnova, O. S. (2011). Termodinamicheskie metody analiza v energoispolzuyuschih protsessah: uchebnoe posobie. SPb GTURP. SPb., 2011, 93 p.

[11] Eideyus, A. I., Koshelev, S. V., Nikishin, M. Yu. Heat transfer and pressure drop at refrigerant boiling in the plate coils. Vestnik Mezhdunarodnoy akademii holoda, 2016, No.2, pp. 42-47. Doi: 10.21047/1606-4313-2016-15-2-42-47

[12] Kudinov, A. A. Energosberezhenie v teplogeneriruyuschih ustanovkah. Ulyanovsk: UlGTU, 2000. 139 p.

[13] Kishkin, A. A., Lavrov, N. A., Delkov, A. V., Mokeev, V. V. (2012). simulation of operating modes of small-productivity refrigeration units. Eng. J.: Science and Innovation, 5 (5), pp. 91-98. DOI: 10.18698/2308-6033-2012-5-187

[14] Sheshunova, E. V., \& Zinovev, K. A. (2017). Matematicheskoe modelirovanie rabotyi teplovogo nasosa. Vestnik APK Verhnevolzhya, 1, 73-78.

[15] Malyshev, A. A., Mamchenko, V. O., Mizin, V. M., Potanina, A. V., Proshin, S. I., Devyatov, T. I. (2013). Perspektivnyie tipy ispariteley holodilnyih mashin. Vestnik Mezhdunarodnoy akademii holoda, 2, pp. 13-18.

[16] Ivanyakov, S. V., Konyigin, S. B. Gidrodinamika nasadochnyih apparatov. Samara; Samar. gos. tehn. un-t, 2008,44 p. http://window.edu.ru/resource/333/77333/files/gad-nasadka.pdf

[17] Kulagin, V. A., \& Pyanyih, T. A. (2013). Raschet rezhimnyih parametrov superkavitatsionnogo isparitelya. In TA Pyanyih. Research Journal of International Studies. Ekaterinburg: OOO Evroprint, pp. 56-59.

[18] Kandlikar, S.G. A general correlation for saturated two-phase flow boiling heat transfer inside horizontal and vertical tubes. J. Heat Transfer, 1990, 112(1), pp. 219-228. Doi: https://doi.org/10.1115/1.2910348

[19] Kompressory holodilnyie ob'emnogo deystviya: metodyi ispyitaniya [Elektronnyi resurs]. 2005. Access mode: https://files.stroyinf.ru/Data2/1/4294826/4294826223.htm. Date of access: 11 November 2019. 